\title{
"What We Do Well": Writing the Pussy Palace into a Queer Collective Memory ${ }^{1}$
}

\author{
JENNIFER BLAIR
}

Jennifer Blair is completing a PhD in English at McMaster

University. Her dissertation focuses on literature and architecture in early North America.

We're happy, not just for ourselves, but that the women who attended were vindicated-in our behaviour, in what we do and what we do well.

— Jill Hornick

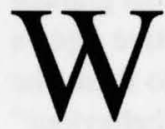

hen Toronto Bathhouse Committee members Rachel Aitcheson and Jill Hornick were dismissed of charges of "disorderly conduct" under Ontario's Liquor Act, they declared the ruling a "vindication." In a statement delivered on the footsteps of the old city hall courthouse after the case, Hornick extended the scope of the decision beyond herself and Aitcheson to all "the women who attended." In doing so, she proffered an understanding that Justice Hryn's ruling would affect Pussy Palace patrons and, most likely, their future participation in similar events.

${ }^{1}$ Many thanks go to Sylvia Bowerbank and Daniel Coleman for helpful comments on this essay in its early stages. I would also like to thank Sharon Rosenberg and the editors of Torquere for their key questions with respect to the Pussy Palace and its losses. Finally, I am grateful to the Social Sciences and Humanities Research Council of Canada for financial support during the writing of this essay.

${ }^{2}$ Hornick and Aitcheson were charged with three counts of disorderly conduct: one count of failing to provide sufficient security, one count of serving liquor outside the prescribed area and one count of serving liquor outside prescribed hours ("Charges"). 
The judge's likening of the search of the Pussy Palace patrons to a strip search (conducted by five male police officers), and thereby a violation of the privacy rights of the women and transgender people who were there, sets a precedent for the "protection" of bathhouses to come. ${ }^{3}$ But it is the curiously worded finale to Hornick's statement that is especially powerful. Hornick concludes that the Pussy Palace patrons should feel vindicated "in our behaviour, in what we do and what we do well" (Gillespie A8). ${ }^{4}$ As part of a list of vindications, "behaviour" and "do" are remarkably ambiguous terms and my project in this article is to make the most of their capaciousnessafter all, just what did the Pussy Palace patrons "do" so "well" before, during, and after the police investigation?

Mixing erotic suggestion and political strategy, Hornick's statement showcases the patrons' two most significant accomplishments. The first is a curious disregard of the court having anything to do with -the outcome, even though it was technically Hryn's decision to disallow the evidence collected in the search that granted Hornick and Aitcheson absolution. In fact, the only active agents Hornick acknowledges in the case are the patrons, and to them she grants almost endless possibilities conjured by the terms "behaviour" and "do." The second accomplishment that Hornick both demonstrates and addresses in her statement, especially by this gesture to a certain active constituency vindicated by this ruling, is the collective community brought about by this occasion-when the Pussy Palace was searched, ruined for the night, and threatened to become lost altogether.

While the Pussy Palace may be understood to have constituted a community prior to the raid, my argument is that this collectivity was founded according to a certain history of loss. Most importantly, it is how the Pussy Palace takes up and responds to its losses that it offers its strongest challenge to anti-queer, anti-sex politics. Taking my cue from Hornick, I argue that the Pussy Palace's most effective politics comes not in the ruling itself-not in the "vindication" by

${ }^{3}$ The search took place at the September 15, 2000 Pussy Palace.

${ }^{4}$ In the CBC Online news article, "Lesbian Bathhouse Raid Charges Tossed By Judge," this statement is attributed to Aitcheson. In an article in the Toronto Star, Loralee Gillis, another Committee member at the time, is quoted as saying, "We feel quite vindicated in this judgment." 
the rule of law-but rather in the articulations of a collective, a collective that refuses to lament the Pussy Palace explicitly and that refuses to celebrate the ruling as the guarantee of a future presence. Moreover, this is a collective whose presence is itself always in question. The discourse surrounding the Pussy Palace case I address here certainly signals a collective, but at the same time this collective is never wholly recognizable and identifiable by the law or even by its own members. Instead, the collective is written into queer collective memory by these writings, remains partial, ambiguously located in time, and shifting in terms of its membership.

Several reports commented upon this collective presence associated with, if not formed by, this case. As Bob Fisher, a ChurchWellesley Neighbourhood Police Advisory Committee member said, "If nothing else, what happened at the bath did something that no one else has been able to accomplish. It actually united the community" (qtd. in Darra). While the implication here that the community had not been united before the Pussy Palace search is perhaps extreme, what it lights upon is the fact that there is something unique about this queer community evident in the responses to it. This uniqueness, I suggest, has to do with the way in which the Pussy Palace is articulated and positioned in terms of loss and, in effect, usurps the law and its visual and auditory practices - its search and identification procedures. Hryn's decision, therefore, did not miss the mark when it hit upon the police search as the lynchpin of the case. And Hryn did not mince his words when he condemned the police as follows: "The search was carried out in an unreasonable manner....There was no reason why male rather than female officers were used...I find the breach to be serious. It was flagrant and outrageous. The charter violations would shock the conscience of the public" (qtd. in Prout). But even with all the semantic might of the decision, the discourse surrounding the Pussy Palace case that was generated outside the courtroom does an even better job of troubling the search. This Pussy Palace writing attests to a community that is at once within the sights and earshot of the law, but at the same time very much capable of turning the tables on the conventions of this perceptual field so that it remains both "lost" and "found"or "never lost"- at one and the same time.

All in all, the Pussy Palace lends itself to a narrative of "lost and found" as much as it does to a narrative of "lost and won," but 
it is the authorities who seem to do both the finding and recovering. In other words, the only place for the Pussy Palace to be is lost, even if Hornick and Aitcheson are not exactly the losers (although they did not technically "win" the case, the case was dismissed when the evidence was disallowed). And "lost" is precisely where it wants to be. To keep with Hornick, the discussion that follows looks to what the Pussy Palace "does" with its loss. The answer that I pursue in the following three sections is this: the writing of the Pussy Palace following the occasion of its own susceptibility to being lost is to produce more loss.

That said, the task of this inquiry into the writing surrounding this case, including pre- and post-raid memoirs, news reports from the mainstream and alternative press, and verbatim text from the ruling, is not to seek out any specific lost object of the Pussy Palace. As I show in the first two sections on memory and the loss of time in the "genre" of bathhouse literature, and in the Pussy Palace documents specifically, readers of these texts find themselves quickly diverted from such a project-if not counseled against it. The third section borrows from an essay by Alys Eve Weinbaum on the gendered nature of modernist writings about loss. Building from her argument that the subject responds to the shocking sights of urban decay or feminine "lack" with a "loss of visual acuity," I interpret one of the most remarkable discursive relics of the case whereby, upon seeing the cops enter the bathhouse, one patron reports to have momentarily mistaken them for butch lesbians (Weinbaum 398). The fourth and final section discusses how, in part through this loss of seeing, the writing surrounding the Pussy Palace helped lose the evidence-in other words, how it produced the loss that led to Hornick and Aitcheson's dismissal and, by association, the collective "vindication."

\section{Remembering the History of the Gay Bathhouse}

As Dianne Chisholm has pointed out, loss is the catalyst for a number of historiographical texts whose principle focus is the gay bathhouse. Discussing Louis Aragon's Paris Peasant, Allan Bérubé's "The History of Gay Bathhouses," George Chauncey's Gay New York: Gender, Urban Culture, and the Making of the Gay Male World, Alan Hollinghurst's The Swimming Pool Library and Samuel Delany's The Motion of Light in Water, Sex and Science Fiction Writing in the 
East Village: 1960-1965, among several other such bathhouse texts, Chisholm suggests that "gay historiography must write against the forgetfulness of mainstream culture. It does so with nostalgia in an attempt to rally collective memory" (244). But for Chisholm this memory of a collective associated with the bathhouse-which includes memories of a collective - is most politically volatile when it violates "readerly perception which looks for homogenous representation of collective space and experience" (259). Working within a paradigm of remembering theorized by Walter Benjamin, in which, contrary to a capitalist dream space of progress and consumer distraction, history is conceived "as a monad, not a spatiotemporal continuum of progress and expansion," Chisholm argues that bathhouse literature is most effective when it troubles this continuum (Chisholm 254). As a whole, her essay celebrates those bathhouse texts which put into play a "technique of seeing history in a dialectical image" where "history - or thinking history - comes to a stop in an image of extreme contradiction" (254). Drawing directly from Benjamin's Konvolut ' $N$ ' of his Das Passagen-Werk ("On the Theory of Knowledge, Theory of Progress" in The Arcades Project), Chisholm explains that this technique involves a specific focus on images and "entails a radical form of citation" (254, original emphasis). If, as Chisholm recalls, for Benjamin, "'To write history means to quote history" then bathhouse literature especially accomplishes this quoting of history, taking place "not as a recitation of what capitalism inventories as success but as a montage of juxtaposed antitheses collected from materials which traditional historicism overlooks as trash and trivia" (Benjamin 476, Chisholm 254). ${ }^{5}$

In general, the arguments that follow situate the Pussy Palace within the history of Chisholm's loosely amalgamated "genre" of gay male bathhouse literature, paying attention to the much overlooked discursive matter ("trashy" matter in some cases) surrounding the case. Broadly, the Pussy Palace writing makes use of so many of the motifs characteristic to gay male bathhouse texts that it easily lends itself to this comparison. But, instead of regarding

${ }^{5}$ The full quotation from Benjamin, also noted by Chisholm, is "To write history thus means to cite history. It belongs to the concept of citation, however, that the historical object in each case is torn from its context" (476). 
these similarities as natural, coincidental, or passively absorbed from one bathhouse text to the next, irrespective of the gender difference of its planners and patrons, I read them as actively (though not necessarily consciously or intentionally) borrowed from the gay male bathhouse literary tradition and its influences. In other words, by "citing" this tradition, to use Benjamin's term, the Pussy Palace writing appropriates its regard for the loss of the gay bathhouse as the impetus for remembering, a remembering that does not correspond to its instigating loss. Even though the texts in question are prompted by the possibility of the bathhouse being lost, they refuse to allow the Pussy Palace to become the ultimate lost object and therefore neatly periodized and slated into the author's memory. Instead, what the Pussy Palace writing remembers is a certain historical process identifiable in the earlier bathhouse narrativesthe process of becoming visible, of becoming known, of identification-a process rendered invisible but made apparent by these predecessor texts' chronicling of occasions when the bathhouse was under threat of being lost.

Delany's The Motion of Light in Water is one text that seems to be recalled by the Pussy Palace writing. In a passage addressed by Chisholm, and earlier by Joan Scott in her essay "The Evidence of Experience," Delany remembers the precarious moments associated with the bathhouse only when he can appropriate their disturbing qualities for his own benefit. For example, Delany recalls a police raid years after the fact when he visits the St. Marks Baths. Since I want to situate this passage as a kind of precursor to several Pussy Palace writings, it is worth quoting at length. As Delany describes in his memoir, St. Marks

was lit only in blue, the distant bulbs appearing to have red centers. In the gym-sized room were sixteen rows of beds, four to a rank, or sixty-four altogether. I couldn't see any of the beds themselves, though, because there were three times that many people (maybe a hundred twenty-five) in the room. Perhaps a dozen of them were standing. The rest were an undulating mass of naked, male bodies, spread wall to wall.

My first response was a kind of heart-thudding astonishment, very close to fear.

I have written of a space at certain libidinal saturation before. That was not what frightened me. It was rather that 
the saturation was not only kinesthetic but visible. You could see what was going on throughout the dorm.

The only time I'd come close to feeling the fear before was once, one night, when I had been approaching the trucks, and a sudden group of policemen, up half a block, had marched across the street, blowing their whistles.

It had been some kind of raid. What frightened was, oddly, not the raid itself, but rather the sheer number of men who suddenly began to appear, most of them running, here and there from between the vans....

What the exodus from the trucks made graphically clear, what the orgy at the baths pictured with frightening range and intensity, was an act that flew in the face of that whole fifties image....

But what this experience said was that there was a population-not of individual homosexuals, some of whom now and then encountered, or that those encounters could be human and fulfilling in their way-not of hundreds, not of thousands, but rather of millions of gay men, and that history had, actively and already, created for us whole galleries of institutions, good and bad, to accommodate our sex. (Delany 173-4)

What sparks Delany's memory is not the police or the numbers of gay men present (even though this mass of people impresses upon him enormously). Instead, it is the similar conditions by which his vision of this image of gay men is compromised by a set of limitations affiliated with dominant regimes of looking, seeing, and identification. For Delany the dim blue light at St. Marks corresponds to the vision of men retreating from the police during a raid of the trucks parked at the end of Christopher Street where gay men met for sex.

In a similar fashion, the Pussy Palace writings remember various procedures of identification put into play by the discovery of a loss. That said, there are some significant differences in the conditions of remembering in which Delany engages and those that pertain to the Pussy Palace. One significant difference, of course, is that the Pussy Palace is a bathhouse exclusively for women and transgendered people. So, while Delany's memory of visiting St. Marks leads to what Chisholm refers to as a "wish image of the future" (266), this look to the future is the result of his "awareness of catastrophe" in the 
"present "era of AIDS"” (Chisholm 266 quoting from Delany 175). Further, as Chisholm argues, it is this catastrophe that "compels Delany to remember the past with political foresight" (266); or-in other words, to engage in a kind of strategic remembering akin to Benjamin's thinking of history dialectically-here, where past and future combine to manipulate this catastrophic present. The Pussy Palace patrons' catastrophe is both similar and different than Delany's. As women, the Pussy Palace authors are well-versed in issues of loss, but at the same time, especially in the era of AIDS, there are some losses which affect them differently than they do gay male bathhouse patrons. Furthermore, as a bathhouse targeted by police, it recalls the closures of bathhouses in the 1980s that prompted the writing of Bérubé's history and portions of several other bathhouse texts, texts which came as the result of various governments' homophobic and misdirected responses to AIDS. In this respect, the loss of the bathhouse and the losses of so many millions of people to this epidemic are linked. Part of the charge of "forgetfulness" has to do with the fact that mainstream culture does its best to forget about AIDS and those who have died of it. This is another way in which, when it comes to queer literature of the past two decades, Chisholm's "rally" of "collective memory" inevitably has political implications. But Chisholm also points out that, where retrospect is a key political tool, this forgetting is no longer entirely lamentable as long as the remembering occurs in a particular, politically effective way as it does in the gay male bathhouse literature like Delany's, and, I would add, in the writing on the Pussy Palace.

The "politics of remembering" that was developed largely out of AIDS activism has come to be useful in responding to a variety of queer-associated losses, including losses of place, of social recognition, of millions of people, of the knowledge of self and of sexual possibility. Often scholarship attuned to this remembering has become less concerned with the lost object and more concerned with the way in which subjects and objects are constituted through the unique dynamics of loss. For such remembering projects have found themselves riddled with the paradoxes that come with loss. By remembering people who have died or remembering queer communities that have gone missing from inclusion in mainstream culture, queers - and writers of bathhouse narratives in particularmust engage the loss of their own community, their own culture. 
The result, as Judith Butler explains, is that "[1]oss becomes condition and necessity for a certain sense of community." But this community "cannot overcome the loss without losing the very sense of itself as a community" $(468) .{ }^{6}$ Remembering, then, is a complicated practice that requires some strategy if it is to be politically effectual but still reckoned with as somehow only partial. When loss is a condition of permanence in the queer community, attempts to altogether recover forgotten people or reinsert queers into the conventions of history have a detrimental effect. On the flip side, partial remembrances can be taken as the sign of a collective unwilling to become unlost. In fact, as the Butler citation above indicates, this is the only way a collective can be signaled without undoing itself in the process. Accordingly, while the significance of the Pussy Palace's foundation of a community is undeniable, this community is not always immediately present in its writing. What's more, overall the consistently elusive references to loss and memory in the writing about the Pussy Palace may do more for the collective's security than the more direct references like Hornick's and Fisher's.

\section{Loss of Time}

Butler's comments about the relationship between loss and community appear in her "Afterword" to David L. Eng's and David Kazanjian's recent collection Loss: The Politics of Mourning. Here, Butler welcomes the "new kind of scholarship" on loss for the way in which it "seeks to bring theory to bear on the analysis of social and political life, in particular, to the temporality of social and political life" (467). When it comes to the loss of place, this new scholarship does not take up the "voice of traditional modernism" that would find in the loss of place a "new place [...] of no belonging, where subjectivity becomes untethered from its collective fabric, where individuation becomes a historical necessity" (468). Instead, it theorizes "a place where belonging now takes place in and through

${ }^{6}$ One descriptor used for the Pussy Palace continued to bother me until I considered it in terms of this melancholia. In an article in eye Magazine, Sky Gilbert called the Pussy Palace a "haven" (2). What troubled me about this statement was its association with a "safe haven" and the coinciding image of women hiding out from the world. But "haven" can also be thought as the place where this loss is harbored, where the loss will remain loss in the productive sense that it leads to so much politically useful discussion. 
a common sense of loss (which does not mean that all losses are the same)" (468). The parallels with the Pussy Palace are more than clear: the collective identifies with their common experience of grieving the loss of the bathhouse. But this belonging does not play itself out in the Pussy Palace writing so directly. At least, while the principal loss at stake is clearly the loss of the bathhouse, this particular loss is never mentioned. There is not a single comment like "the Pussy Palace might not happen again" or "the Pussy Palace will never be the same again." Instead this writing catalogues a wide variety of losses that do not map easily onto the presence or absence of the Pussy Palace.

One of the most significant losses attached to bathhouse culture is the loss of female sexuality. Janet Rowe, another Pussy Palace committee member at the time, commented that "A lot of women have not had the freedom to explore their sexuality...After all, young girls are not taught that their sexuality is theirs, for their own pleasure" (qtd. in Silversides). What is significant about Rowe's comment is that women's lack of knowledge of their own sexuality is a kind of loss that pre-dates the threat to the Pussy Palace. It is a loss that is addressed at the moment of this threat, but it may still be the condition of the Pussy Palace's significance even when its discontinuation is less and less likely.

There were also several remarks about the loss of any possibility of forming a working relationship with the police. City Councillor Kyle Rae lamented loss of time spent building this relationship since the 1981 Toronto bathhouse raids when more than 300 gay men were arrested on a single night: "This police action takes us back 20 years" (qtd. in Nolen and Freeze). Making matters worse, Lee Zaslofsky suggested that "there may never be a good time" to reestablish this lost relationship (qtd. in Carmichael). Zaslofsky's comment signals the prevailing sentiment of the collective to "never forget" the police raid. ${ }^{7}$ In other words, not only was the memory of the search to be kept sacred, but also the threat of the loss of the Pussy Palace was guaranteed to endure into the future. Hornick and Aitcheson's lawyer Frank Addario echoed this gesture to the future by hoping that "this kind of thing won't happen again" (qtd. in Gillespie A8).

${ }^{7}$ Michelle Hamilton-Page stated "We're not forgetting, they [the police] can do as much PR as they want" (qtd. in Nolen and Freeze). 
The danger in comments that lament an uncertain future, however, is that they tend to attribute too much power to the police. As Chisholm argues, "If we attribute the loss of this space to mainstream homophobia, we merely concede that history belongs to the victors" (269). Indeed, history does seem to belong to the police if they can whisk away twenty years of queer activism in a single night. However, we might say (as Hornick has) that in the case of the Pussy Palace, for once it is the bathhouse patrons who are the victors. In this instance, it is important to acknowledge just how they assumed this role and, especially, what they make of the "history" that now "belongs" to them. If "victory" means to assume and to occupy a certain place in time and a certain place in the city-i.e. the bathhouse-then the writings of the Pussy Palace, instead, identify with but ultimately disavow this privilege by keeping the loss of the bathhouse as something in the recent past and the potential future. When the Pussy Palace loses its place in time, it becomes much more difficult for it to be a lost place. In other words, if the Pussy Palace is a place that used to exist (existed at a certain notch on a timeline) and now does not, then it is easy to recognize as lost. But in these writings it is something different: it travels back in time and is projected into the future. Even though the event of the raid would seem to want to fix the Pussy Palace as something that occurred up to the point of its occurrence and the charges that resulted, in fact it prompted these responsive writings that snatch it out of the linear historicity to which the oppressive authority that likes bathhouse closures depends.

\section{Loss of Sight: "Not Butch Lesbians"}

As will be apparent by now, the Pussy Palace case fits with uncanny neatness into an Althusserian scene of subjection. This is the one in which the police officer calls out to an individual who turns to this figure of the law and becomes a subject by virtue of this very turning. This is a turning that signals not just an identification with the name but also, as Butler argues, with its implication of guilt. ${ }^{8}$ Drawing

${ }^{8}$ In The Psychic Life of Power: Theories in Subjection Judith Butler offers a critique of the conditions of this call. One aspect of her argument relevant to my discussion is the way in which the subject's turn to the law involves also assuming a loss of all of itself that was not identified in the hail (106-131). 
attention to the significance of the "call of the law" of the Pussy Palace case, Mariana Valverde, as quoted on CBC Radio news the evening of the ruling, pointed out that "[a]ll of the cases around bars and so on have always been with men, and this is the first case that involved women." Are these women and trans people called by the law the same as the collective noted by Fisher, by Hornick - the same as that queer collective with a certain political agency of Chisholm's analysis?

While one of the most powerful aspects of Althusser's model is its didacticism, it is important to locate possibilities for some discrepancy between the authorities' hail and the subject's response, and also between this theoretical narrative and the events of the Pussy Palace case. On the one hand, there are undeniable privileges to being recognized as subjects with rights protected under the Charter; yet, on the other, to welcome this absolution of guilt when, before the case, guilt was not a possibility, seems terrifically misguided-as does the feeling of relief from future police harassment. After all, how does this become such a relief, when at one time the Pussy Palace patrons did not concern themselves with the possibility of a police visit? Now named by the law, it seems we remain precariously at the mercy of the court that may or may not continue to differ from police procedures. Our official inauguration into the public depends entirely upon the way in which the authorities see us, and this condition will survive beyond the legacy of the police having bungled its initial identification. But how does a collective formed out of the event of a police search identify outside the range of its scope? What or where is this other place and how do its members collect and articulate themselves there?

As noted above, the Pussy Palace writing makes use of some techniques outlined by Samuel Delany in his own memoir of a police raid of the trucks. As Scott argues, one of the most important aspects of this memory (redoubled by the fact that it takes place in a memoir) is its emphasis on the visual. It is significant that Delany

${ }^{9}$ Valverde, a criminologist at the University of Toronto, may well have been testing the specific effects of such a naming, rather than confirming its authority. In a column in Xtra! a few days later she voiced some concerns over the position of transgender people in this ruling that otherwise resorted to a fairly strict gender dualism (see Valverde, “A Pussy-Positive Judgement”). 
forgets about the trucks until he visits the St. Marks Baths and is struck with fear at being able to "see what was going on throughout the room" (173, my emphasis). What Delany recalls about the trucks that bears some resemblance to the scene at the bathhouse is that "what frightened was, oddly, not the raid itself, but rather the sheer number of men who suddenly began to appear, most of them running, here and there from between the vans" (174). Delany concludes: "What the exodus from the trucks made graphically clear, what the orgy at the baths pictured with frightening range and intensity, was an act that flew in the face of that whole fifties image" of the "isolated" gay man (174). Notice that Delany's memory of the trucks explicitly disregards the police as having anything to do with his realization. Rather than declare that his "fear" is the result of the raid, he attributes it to "the sheer number of men who suddenly began to appear." But even more than this, Delany also claims that "it was the contradiction with what we 'knew' that was fearful" (174). In other words, what Delany sees is different than what he knows about what it means to be gay. By seeing men flee the police, he sees that this image of isolation was produced by the social violences such as this police raid.

To paraphrase Scott, seeing is still the origin of knowing here, but only in a circuitous kind of way. What Delany sees are the historical processes of subjection in addition to the various authorities and subjects involved. Delany is fearful because, having experienced this contradiction with what he "knew," there is so much more uncertainty with respect to his own sense of self and the world at large. This is the uniquely paradoxical situation that comes with the police raid-it accomplishes at least as much collective identification on the part of its so-called queer "victims" as it does monger fear and reproduce the image of queer isolation. The fact that the raid must undertake an optical investment to accomplish what it wantsagain, this "image" of gay isolation-guarantees that it will pave the way for an alternative image of an amassed queer collective identity. This is in fact what happens with Delany, who identifies with a collective "we" that has been coerced into identifying under this false "knowledge" of the gay man. As Chisholm explains, "The 'I' of Delany's memoirs becomes the 'we' of history's collective assembly the moment straight urban mythology is revised by politicized memory" (266). 
It is important to remember that Delany is only able to see this "we" when he is at the bathhouse, remembering a police raid but not presently subject to one. As Scott and Chisholm both argue, although to quite different ends, it is not so much the masses that trigger Delany's memory. Rather it is a process of seeing in a visual field subject to constraint that, by the time he is at St. Marks, Delany is able to identify and appropriate for the purposes of his own envisioning. In other words, Delany can reproduce optic limitation without the imposition of the police. His substitution for the blue uniforms of the N.Y.P.D. is the uniformity of a blue light. As Scott concludes, it is the blue "wavering light" that "permits a vision beyond the visible, a vision that contains the fantastic projections...that are the basis for political identification" (410). Through this police search of the past, Delany comes to participate in a practice of seeing, one that was called to his attention by the police, but that leads to different visions and consequences. Most notably, it leads not to the elimination of gay men from public knowledge and sight, but rather to their inclusion in it.

Just as it does in Delany's memoir, the "call of the law" comes to an interesting impasse in the following passage in an article by Josey Vogels on the Pussy Palace raid. Like Delany, Vogels appropriates something of the practice of seeing brought by the police in order to turn the raid into a moment of productive queer envisioning. But, while Delany experiences the loss of an image of himself in favour of one of a collective, in Vogels' article this loss is something experienced by the police at least as much as it is by the Pussy Palace patrons. Vogels writes:

....after an exploration of the sweaty dance floor, the sauna and the "fun room," ...I suddenly look up and see five guys making their way through the variously clad women.

Just for a second, I imagine they might be really butch lesbians, but, oh, horrors, they're plain-clothes cops. (27) To appreciate the effect of Vogels' observation, I draw from Alys Eve Weinbaum's "Ways of Not Seeing: (En)gendered Optics in Benjamin, Baudelaire, and Freud." Like Delany, and like Chisholm's analysis of his memoir, Weinbaum focuses on the event of catastrophe or "shock," as she refers to it, as the catalyst for a kind of subjection. Comparing the related shocks theorized by Benjamin and Freud-for the former it is urban decay, for the latter it is the 
sight of female genitalia understood as lacking-she points to the way in which both thinkers are "actively involved in the production of modernity as visually destabilizing and, more specifically, in the production of the loss of visual control as a principal index of gender identity" (398). In short, the loss of the ordered city and the loss of a genital organ generate this perceptual loss-a loss of sight. What is most significant, however, is that for both Freud and Benjamin the viewer substitutes a woman for the disagreeable sight before them. The image of the woman becomes the pleasurable "alteration of the visual field" through which the viewer is "able to come to terms with what he sees on "first sight"" (403).

Without going into detail about the theories of the flaneurism and fetishism in question-Weinbaum does a comprehensive job of this in her article-I provide a brief summary of her findings. Overall, Weinbaum's article responds to the "scholarly consensus that the objectification of woman in the male field of vision has often served as the ground for securing coherent masculinity." It also engages directly with the "now familiar argument" that "when woman is transformed into a fetish object she guarantees the viewer's control over the visual field" (398-399). However, in seeking to "modify this formulation," she suggests "that the male gaze is a construct best characterized not so much by control, mastery, or prowess as by the momentary loss of all three" (399).

If Weinbaum's overall project is to point out that this gendered and gendering loss of seeing is the "product" of modernist theories of subjection, then Vogels puts this product to her own good use. By replacing the cops with butch lesbians, even if only momentarily, she follows the track of the male subject who "must create a momentary loss of visual acuity and a phantasmatic claim that in fact the visual field is occupied by something much less shocking and far more reassuring" (398). There are several ways to read Vogels' "not butch lesbians" comment alongside the modernist tradition of the male gaze-whether we understand this tradition as one of visual mastery or as Weinbaum's "loss of visual acuity." Immediately we might say that Vogels locks the search within a paradox of gendered observation. If this paradigm of the male gaze informs the Pussy Palace search - and, in a sense, Justice Hryn ruled that it did-what were the cops to see there? On the one hand, they pressed charges of "disorderly conduct" as if there was an initial 
shocking vision that was never fully transformed into a placating image of a woman, or several women. By citing this paradigm of men seeing or losing their ability to see, Vogels calls to the fore what must be, according to this very paradigm, an impossible situation: they must maintain some control over their field of vision in order to find "disorder," but they cannot do this if they are to complete the program of the male gaze-that is, to accomplish the alteration of vision that confirms their masculinity.

But how does the cops' trouble with seeing come to be something that Vogels experiences herself? One response to this question requires a step back from Weinbaum and a return to Benjamin directly. In his "On Some Motifs in Baudelaire" (the essay that Weinbaum draws from extensively), Benjamin writes, "the person we look at, or who feels he is being looked at, looks at us in turn. To perceive the aura of an object we look at means to invest it with the ability to look at us in return" (188). This notion that a transfer of the act of looking can occur, and precisely the "ability" of the act of looking, speaks directly to Vogels' description of what takes place at the Pussy Palace. However, if Benjamin points to the "ability" of a person and, subsequently, the aura of an object to "look at us in return," then with Weinbaum we might add that it is possible to invest the object of our gaze, or the object of the male gaze, with an inability to look. Is it possible that Vogels' claim to having mistaken the cops for butch lesbians functions to announce that she has acquired their loss of visual acuity, calling attention to their inability to look? If their loss is hidden or silent, Vogels not only makes it pronounced, but appropriates it into a fantasy of her own pleasure. Strangely enough, the search becomes a vehicle for the enunciation of queer desire. In the process it undoes the gendering work of such processes of seeing insofar as the pleasurable afterimage does not secure the difference between men and women.

It is important to clarify that in the passage quoted above, Benjamin specifies that the ability to look occurs when the "aura of the object" is perceived. The "aura" is the cluster of associations of the mémoire involuntaire. Borrowing the term from Marcel Proust, Benjamin explains that the mémoire involuntaire is "only what has not been experienced explicitly and consciously, what has not happened to the subject as an experience" ("On Some" 160-161). Like Weinbaum, Benjamin addresses the possibility of an inability 
to look, but in this essay on Baudelaire he focuses on the inability of an object to return the gaze of the subject. Furthermore, while Benjamin makes several observations about the nature of this loss of experience, revisiting the work of Proust, Baudelaire, Freud and others, what his discussion emphasizes overall is the impact of this persistent loss of which the aura is evidence. As the object of the cops' gaze, the fact that Vogels cannot see them properly in her returning gaze confirms that there is indeed a loss that will perpetuate in this scenario. To keep with Weinbaum, as long as the cops see the patrons as a specifically feminized fetish object, they will indicate the presence of an aura constituted by what they refused to experience - that is, the less distinctly gendered male / female environment they witnessed upon entering the Pussy Palace.

Several articles in addition to Vogels' confirm that the police indeed participated in this feminized replacement process, emphasizing the cops' trouble with seeing in their interpretations of the search. Kyle Rae, for example, called the search an "ogle fest" undertaken only so that the police could "cop a peek" at the patrons (qtd. in Brown). One patron accused the cops of "leering" at her and another reported that one police officer tried to "stare" her down (Irwin 13). Nancy Irwin also recounts the experience of T'hayla, who "had to ask an officer who was frozen in a stare at her uncovered breasts if she could 'help him with something.' That broke his concentration, and he said 'no"' (12-13). If Vogels made the cops' trouble with seeing present by actively returning their gaze, then T'hayla identifies this problem by offering them "help." Of course, in the scenario that Weinbaum assesses, the male gaze does require the help of a woman, but undoubtedly the receipt of this offer of help compromises the "mastery" and "prowess" they seek to achieve from looking at women.

One last comment about the cops' trouble with seeing worthy of mention comes from the decision itself. Hryn said that " $[t]$ he male officers knew patrons would be in various states of undress in a highly sexualized environment but didn't search for female officers" (qtd. in Gallant). If the above-cited comments focus on the visual ability of the cops, Hryn's adds that the object of their search was misidentified in the first place: they should have searched for female officers, thereby directing their gaze more or less to their own collective, rather than for illegal activities of the bathhouse patrons. 
The eventual outcome of this trouble with searching and seeingnot to mention the lack of searching for female cops-is that the police lose the Pussy Palace, as an object to be secured, in their search.

\section{Loss of Evidence}

Having displayed a certain inability to see when conducting the search, it is unlikely that the police had collected any useful evidence should the court have allowed it. Evidence has been a matter of concern for bathhouse narratives to date-even those that do not involve a court case - and so the fact that the Pussy Palace's verdict came down to a question of evidence is fitting. In terms of loss, the Pussy Palace's production of this loss of evidence is perhaps the most significant because it led to the dismissal. Still, to appreciate just how the Pussy Palace "tampered," one might say, not just with the evidence the police gathered but with its status as a representative of "truth," requires returning to earlier bathhouse narratives in which the conventional notion of evidence has come under question. Extending the strategies of these earlier texts, the Pussy Palace writing does not seek to solve the problem of evidence only by directly contesting the evidence collected to substantiate the charges against them. Instead, it recasts the processes of evidence gathering by treating evidence as a manufactured product rather than a relic discovered and poised to serve as the sign of the truth.

As writers from Delany to Chisholm to Scott have made clear, there is little reason to put any faith in the usefulness of evidence when so much of queer experience is lost, or violently extricated, from public memory. These writers are skeptical of solving this dilemma by simply arguing for the inclusion of queer people into the public record-for, as Delany points out, when it comes to remembering lost things, the public record may always be at odds with individual queer memory. In fact, Delany refuses to relinquish his memory of the date of his father's death when the "truth" is presented to him in a paper record of official history. Keeping the two possibilities in play becomes an aesthetic motif for his entire autobiography, a refusal to give the last word to "event and evidential certainty" (xviii). What is remarkable about Delany's memoir is that it does not resort to what Scott identifies as the more conventional "referential notion of evidence which denies that it is anything but a 
reflection of the real," even though his project is to give evidence to a relatively silent, pre-Stonewall queer life in New York City (Scott 399). Instead, Delany offers his experiential narrative, and particularly his first trip to St. Marks "not as the discovery of truth (conceived as the reflection of a prediscursive reality), but as the substitution of one interpretation for another" (Scott 410). Scott continues that for Delany there is no single answer to the question "What does it mean to be black, gay, a writer?" Rather "the meanings of the categories of identity change and with them the possibilities for thinking the self" (410). If we map this alternative historical approach onto the Pussy Palace, we might come up with the following: there is no single and historically enduring Pussy Palace patron who becomes visible under a police search or under an experiential memoir of this search. Instead, the search brings with it a certain requirement for evidence, and the patrons become variously constituted according to the responses to these requirements made by all parties involved.

Where Delany's memoir refuses to remain "so comfortably within the disciplinary framework of history" (399), to borrow another phrase from Scott, Alan Bérubé's "History of Gay Bathhouses" falls comfortably into this framework-so much so that it is quickly and easily subsumed by the parallel and politically bereft narrative of consumerism. This is a second problem with evidence featured in bathhouse narratives. As Chisholm explains, Bérubé offers his experience up to his readership as evidence of queers' right to space in the city, arguing that the "gay community has a right to be and be there, like any other established community in America, guardian of democracy and home to all enterprising minorities" (Chisholm 245). In other words, Bérubé recounts the history of the bathhouse as a liberalist narrative of emancipation. However, as he describes the development of the bathhouse over time, he gets caught up in the details of its material growth. With increased attention to bathhouses' successive appropriation of gay urban space, including their developments in interior decoration and their investment in "fantasy environments," his history focuses on "property acquisition and 'refurbishing' as much as appropriative, spatial and social practices" (Chisholm 250). The result is that "activist historiography also appeals to entrepreneurial progressivism, thereby undermining its political radicalism" (Chisholm 250). 
For Chisholm, several bathhouse narratives go the route of Bérubé's:

...historiography of the gay bathhouse compromises its socialist discourse with a narrative of growth and development, whereby production implies reproduction and consumption, appropriation implies commercialization and renovation, and social space is confused with the phantasmagoria of the capitalist marketplace. In a conflation of rhetorics, the gay bathhouse figures now as a commune, then as an arcade. (249)

This "conflation of rhetorics," however, is not a problem in itself. It becomes a problem when "liberal historiography obscures" the "contradictoriness" of capitalism in and through such "narratives of growth and prosperity" (Chisholm 269). The Pussy Palace, however, works the relationship between the social and commercial narratives differently. Instead of conflating the two, the Pussy Palace writing uses the commercial to upset the social. In particular, its treatment of evidence as a manufacturable product, rather than the deliverer of truth and justice, distances the patrons from the narrative of losing and finding, hidden and visible, that is fundamental to the police search as well as to conventional liberalist narratives of social emancipation.

There are a number of examples in which the discourse of the Pussy Palace makes use of commercial rhetoric. Sky Gilbert refers to it as a "supermarket" (1) and Carlyle Jansen ends a post-raid article with an invitation to "stay tuned to the bathhouse channel" (19). What is interesting about Jansen's comment in particular, however, is that it identifies the Pussy Palace's commercial accomplishments as having less to do with the acquisition of things and more to do with the commodification of information. To the extent that they produce visual media, TV channels - and, as we shall soon see, Polaroidstake over from Delany's “blue light.” In Delany's opening description of St. Marks Baths, "[i]t was lit only in blue, the distant bulbs appearing to have red centers," the "blue" and "only" light makes a population visible to Delany, but also puts constraints upon that vision so that he will only ever be able to "know" this population in a certain way (173). At the Pussy Palace, there is less focus on an obscuring of vision and more on the manufacture of images.

According to Chisholm, gay bathhouse authors such as Bérubé "must see that his historical object cannot be redeemed until he 
detaches it from the capitalist narrative of progress and criticallydialectically - reconstellates the space of its production" (252). Even though the Pussy Palace welcomes rather than detaches itself from commercialism, it does "reconstellate the space" in which evidence is obtained. In fact, the Pussy Palace gives evidence its own production space, instead of treating it as something already there, haphazardly found, and reinserted as an object of history. While Bérubé's history, at least according to Chisholm, falls prey to the imposition of a capitalist narrative that stays hidden under the acknowledged one of liberalist emancipation (losing its political effect as a result), the Pussy Palace foregrounds the commercial by making this space for the making of evidence. But what exactly is this space?

The Pussy Palace made a space for the production of evidence in the form of a "photo room," a place where the patrons could have Polaroid photos taken of themselves to document their night at the bathhouse. In other words, this was a place where evidence-gathering became an event, a place where patrons immediately knew that evidence could be obtained. Of course, the photo room was designed to serve the patrons who wanted to engage in the activity of producing a visual memory of their trip to the bathhouse in the form of takehome souvenir snapshots. As such it had nothing to do with the police. When the police arrived, however, the photo room did come under scrutiny. The result was that its significance as a place to get evidence was intensified, but also confused by a kind of conceptual short-circuiting that occurred when the police, looking for "evidence" in their search, found a place already "in place" to get some. Vogels recalls how "leader of the pack," inspector David Wilson

...thinks he's hit the jackpot when he spots a sign on the wall indicating the "porn/photo room."

He points to it as if it's the devil, and repeatedly grills a rather unassuming volunteer. "What is this? Where is this?"

It turns out to be one room where women can watch porn videos and another where women can have "my night at the bathhouse" souvenir Polaroids taken.

Wilson harrumphs and confiscates the sign as "evidence." (27)

The joke here is that Wilson confiscates as evidence a sign for a particular room at the bathhouse where the patrons can get a piece 
of evidence of their own. Clearly the room throws the whole police search into some turmoil, since its primary goal to "find" evidence is no longer necessary-presumably, they can take all the snaps they want. In this way, it is almost as if Wilson and his co-officers come to participate in one of the services already provided by the bathhouse. However, being provided with the means to make evidence by the subjects of their search proves to be only a burden to them. The sign is only evidence of a place to get evidence-and, in the end, it only signals the fact that the police are unsuccessful at acquiring any evidence in this place. Moreover, if the only evidence on offer actually in this room is a personal Polaroid, all that the police will be able to prove is the fact of their own presence at the bathhouse. In coming away with the sign for the photo room, they collect evidence of evidence yet-to-be-had. Were they to come away with Polaroids as well, they would only further the argument begun by Delany. For these Polaroids, which could only be of themselves, would remind any judge or jury that any evidence of an experience is limited by the unique perspective of that experiencing individual.

If, for both Scott and Chisholm, the enlightenment narrative of becoming visible and/or acquiring rights to social space is riddled with problems of evidence-its historically conservative processes or its susceptibility to capitalist fantasy - then the Pussy Palace plays the two off against one another. Like the more successfully political bathhouse narratives that Chisholm discusses, the Pussy Palace writing does not allow the narrative of emancipation to "obscure" capitalism's obsession with products. Instead, the product-value of evidence, including the value of the pleasure taken in producing evidence, remains in the foreground.

\section{"Rhetoric" of Loss}

Parts of the discussion above may seem to contravene the celebratory atmosphere brought by the outcome of the Pussy Palace case. It's been more than three years since the ruling, and I do not intend to put a damper on the ongoing festivities. On the contrary, I hope to have highlighted the political brilliance of Hornick's statement, Vogels' article, and the several other remembrances like them. After all, there is much more to be celebrated about the Pussy Palace case than has been up to this point. 
Some of the Pussy Palace's best successes are to be found in the writing surrounding the case. Certainly these documents seem to accomplish much more, politically speaking, than the discourse pertaining directly to the court proceedings. Perhaps the best indicator of the value of this material comes from then Toronto Police Chief Julian Fantino. When Fantino tried to dismiss the discussion surrounding the search just days afterward by stating that "so much of it is rhetoric right now," he called attention to the very arena in which police authority is extraordinarily vulnerable (qtd. in Quinn). The "rhetoric" surrounding the Pussy Palace takes aim at this vulnerability. When much of the media focused on the apparent vulnerability of naked women under the searching eyes of male police, it is important to acknowledge how the Pussy Palace writing demonstrates, in Weinbaum's terms, a "mastery" of the relationship between language, authority, and processes of identification. But this mastery is one that exercises a keen knowledge of loss. By way of manipulating these processes to their advantage, the Pussy Palace writing infuses them with loss or makes known the losses that are already a part of them. As a bathhouse, and in particular a women's bathhouse, the Pussy Palace has a certain amount of experience when it comes to loss. As a result, the police come up empty-handedwell before Justice Hryn disallowed the evidence they gathered in the search.

\section{Works Cited}

Benjamin, Walter. "On Some Motifs in Baudelaire." Illuminations. Ed. Hannah Arendt. Trans. Harry Zohn. New York: Schocken, 1968. 155-194.

- The Arcades Project. Trans. Howard Eiland and Kevin McLaughlin. Cambridge and London: Harvard UP, 1999. Rpt. 2002.

Bérubé, Alan. "The History of Gay Bathhouses." Policing Public Sex: Queer Politics and the Future of Aids Activism. Ed. Dangerous Bedfellows. Boston: South End, 1995. 187-220.

Brown, Eleanor. “Male Cops at Pussy Palace.” Xtra! 21 Sept. 2000. 11.

Butler, Judith. "After Loss, What Then?" Afterword. Loss: The Politics of Mourning. Eds. David L. Eng and David Kazanjian. Berkeley: U of California P, 2003. 469-473. 
. “'Conscience Doth Make Subjects of Us All': Althusser's Subjection." The Psychic Life of Power: Theories In Subjection. Stanford: Stanford UP, 1997. 106-131.

Carmichael, Amy. "Police, Gays to Form Liaison Committee." Globe and Mail. 18 Sept. 2000: A18.

“Charges Laid.” Xtra! 6 October, 2000. Pussy Palace Website. 7 Feb. $2002<$ http://www.pussypalace.com>.

"Lesbian Bathhouse Raid Charges Tossed By Judge." CBC Radio News. 1 Feb. 2002. <http://www.cbc.ca/>.

Chisholm, Dianne. "Love at last sight, or Walter Benjamin's dialectics of seeing in the wake of the gay bathhouse." Textual Practice 13.2 (1999): 243-272.

Darra, Irene. "The cop speaks." Xtra! 5 Oct. 2000, 14.

Delaney, Samuel. The Motion of Light In Water: Sex and Science Fiction Writing in the East Village, 1957-1965. New York: Arbor House, 1988.

Gallant, Paul. "Pussy Palace Charges Dropped." Xtra! 31 January 2002, 11.

Gilbert, Sky. "Bathhouse raid a sexist outrage" Eye Online. 21 Sept. 2000,1-3 <http://www.eye.net/eye/issue/issue_09.21.00/ columns/pink.html>.

Gillespie, Kerry. "Police raid abused rights of women: Two cleared of charges after lesbian party." Toronto Star 1 Feb. 2002: A1+. Irwin, Nancy. "Police Raid Women's Bathhouse Party." Siren (Oct./ Nov. 2000): 12-14.

Jansen, Carlyle. "Our Pussy Palace Adventure." Siren (Oct./Nov. 1998): 18-19.

Nolen, Stephanie and Colin Freeze. "Bathhouse Raid Angers Lesbian Community." Globe and Mail. 16 Sept. 2000: A27.

Prout, Janet. "Charges Dropped in Lesbian Baths Raid." PlanetOut. 12 Feb. 2002. <http://www.365gay.com/>.

Quinn, Jennifer. "Fantino Criticizes 'Rhetoric." The Toronto Star. 19 Sept. 2000: B3.

Scott, Joan. "The Evidence of Experience." Rpt. In The Lesbian and Gay Studies Reader. Eds. Henry Abelove, Michele Aina Barala and David M. Halperin. London: Routledge, 1993.

Silversides, Ann. "The Paw That Scratches: The Pussy Palace Raid has Galvanized the Lesbian Community to Fight Back." eye 
Magazine 14 June 2001. Pussy Palace Website. 15 Feb. 2002. $<$ http://www.pussypalacetoronto.com/ $>$.

Valverde, Mariana. “A Pussy-Positive Judgement.” Xtra. 7 Feb. 2002: 18.

Vogels, Josey. "Polite Gal Love." Now 20.3 Sept. 21-27, 2000: 27. Weinbaum, Alys Eve. "Ways of Not Seeing: (En)gendered Optics in Benjamin, Baudelaire, and Freud." Loss: The Politics of Mourning. Eds. David L. Eng and David Kazanjian. Berkeley: U of California Press, 2003. 396-426. 